\title{
REVIEW OF NUTRACEUTICAL USES OF AN ANTIOXIDANT SUNFLOWER SPROUT, HELIANTHUS ANNUUS
}

\author{
WANNEE JIRAUNGKOORSKUL* \\ Department of Pathobiology, Faculty of Science, Mahidol University, Bangkok 10400, Thailand. Email: wannee.jir@mahidol.ac.th
}

Received: 16 May 2016, Revised and Accepted: 25 July 2016

\section{ABSTRACT}

The concept of "clean food or green food" is very popular in the present lifestyle. The green sprouts have been an increase in consumers' demands such as alfalfa (Medicago sativa), broccoli (Brassica oleracea), lentil (Lens culinaris), mung bean (Phaseolus aureus), radish (Raphanus sativus), soybean (Glycine max), sunflower (Helianthus annuus), and other seed sprouts that are usually eaten fresh or cooked for beverages, soups, appetizers, or main courses. Not only are the delicious menus but the sprouts also considered to provide health benefits. H. annuus is a folk remedy for chronic diseases such as bronchiectasis, cough, diarrhea, hypertension, infection, and rheumatism. Its phytochemical substances are alkaloids, carotenoids, flavonoid, minerals, oils, phenols, tannins, terpene compounds, and vitamins, which all of these contribute to its remedial properties. This review is an attempt to compile information on nutraceutical uses of sunflower sprout, H. annuus in the antioxidant property.

Keywords: Antioxidant, Helianthus annuus, Plant, Sprout, Sunflower

(C) 2016 The Authors. Published by Innovare Academic Sciences Pvt Ltd. This is an open access article under the CC BY license (http://creativecommons org/licenses/by/4. 0/) DOI: http://dx.doi.org/10.22159/ajpcr.2016.v9i6.12874

\section{INTRODUCTION}

Sprouts are shoots of germinated seeds, which are excellent sources of proteins, vitamins, and minerals [1]. They can be used the clean food in salads, soups, stews, and casseroles in the past few decades from Far Eastern countries to parts of the Western world [2]. The common types of seeds used for sprouting are alfalfa, amaranth, broccoli, cabbage, lentil, mung bean, radish, rice, rye, soybean, sunflower, and wheat seeds [3]. As the sprouts are consumed at the beginning of the growing phase, their nutrient concentration remains very high [4]. In naturopathy, sprouts have the medicinal benefits; they can be promoting health aspects and safety evaluation [5]. The U.S. Food and Drug Administration has published several recommendations to consumers regarding consumption of sprouts [6]. The sunflower Helianthus annuus is the core of medicinal values which is used as food and medicine worldwide [7].

\section{TAXONOMICAL CLASSIFICATION OF H. ANNUUS}

The generic name, Helianthus, is derived from Greek "helios" meaning the sun and "anthos" meaning a flower. The taxonomy of H. annuus is in the kingdom (Plantae); subkingdom (Tracheobionta); superdivision (Spermatophyta); division (Angiospermae); subdivision (Eudicots); class (Magnoliopsida); subclass (Asteridae); order (Asterales); family (Asteroideae); genus (Helianthus); species (H. annuus) [8,9].

\section{NOMENCLATURE}

H. annuus is commonly found to be grown in Africa, Australia, and Asia [10]. The vernacular name of $H$. annuus is also known as (English) sunflower, (Afrikaans) sonneblom, (Albanian) lule dielli, (Arabic) abbâd esh shams, azriyun (Brazil) girassol, (Catalan) corona de rei, heliantem, (Chinese) kui hua, xiang mu kui, zhang ju, (Corsican) girasole, (Croatian) džirasol, jednogodišnji suncokret, krumpir morski, (Czech) slunečnice roční, (Danish) almindelig solsikke, solsikke, (Dutch) engelse zonnebloem, (Esperanto) sunflora, (Estonian) harilik päevalill, (Finnish) auringonkukka, isoauringonkukka, (French) grand soleil, soleil, tournesol, (German) echte sonnenblume, sonnenblume, (Hawaiian) nānālā, pua nānālā, (Hungarian) napraforgó, (India) beliphul, surjmukhi, (Indonesia) bunga matahari, (Italian) corona del sole, girasole, (Japanese) himawari, koujitsuki, (Korean) hae ba ra gi, (Latvian) vasaras saulgrieze, (Lithuanian) tikroi saulègrąža, (Malaysia) bunga matahari, (Niuean) matalā, (Norwegian) solsikke, solvendel,
(Persian) aftabi, azriyun, (Philippines) mirasol, (Polish) slonecznik roczny, slonecznik zwyczajny, (Portuguese) giganta, gyrasol, (Russian) podsolnechnik, (Samoan) mata o le lā, (Slovašcina) navadna sonènica, (Spanish) alizet, copa de júpiter, (Swahili) alizeti, (Swedish) solros, (Thai) taan dtà-wan, (Turkish) ay ciç, gün ciç, (Vietnamese) hoa mặt trò̀i [11].

\section{GROWING SPROUTS}

The morphology of sunflower seed is black tear-dropped shape or conical pericarp, or hull, smooth surface, and gray strips. Although there are several ways to sprout seeds, the most common starts with seed measurements (Fig. 1a): This is the amount of seeds to use per jar or blanket or tray and varies from seed to seed as they differ in size; soaking time (Fig. 1b): Most all sprouts, need to be soaked at least $8 \mathrm{hrs}$ in advance before the actual sprouting process can take place; damp towel (Fig. 1c): Place the seeds in the damp towel and fold the towel up so that they are covered and place the towel in a resealable plastic bag 24 hrs at least. During this period, the seeds should begin to sprout (Fig. 1d). Sprouting time (Fig. 1e): Spread the seeds across the tray with either a soil medium, coconut coir or vermiculite, place the second tray on the top of the soil, and place both the trays in a cool dark place about 3 days but check and water on them every day. Remove the upper tray when they grow up about an inch height (Fig. 1f) and place the sprouts in a sunny location (Fig. 1g). Seeds germinate quickly and will be ready to cut, at soil level (Fig. 1h), in 6-9 days. Seedling, at their two-leaf stage (Fig. 1i), is referred to as sunflower lettuce. If left to grow any older, they are bitter and rather unpalatable.

\section{FACTORS INDUCED SPROUTING}

Xing et al. [12] study the effects of light spectral energy distribution of the light emitting diode on the growth and quality of $H$. annuus sprouts. Fluorescent light was used as the control. The results showed that on the condition of light intensity $23 \mu \mathrm{mol} \mathrm{m} \mathrm{m}^{-2} \mathrm{~s}^{-1}$, photoperiod $14 \mathrm{hrs} /$ day, and temperature $25 \pm 2^{\circ} \mathrm{C}$, red light could significantly increase the cotyledon area, the hypocotyl diameter, the starch content and the chlorophyll to carotenoid ratio of sunflower sprouts. Besides, compared with other treatments, red light could improve the content of chlorophyll a, total chlorophyll, and carotenoid remarkably. Blue light obviously increased the accumulated amount of dry weight, soluble protein, and the activity of antioxidant enzymes. Yellow light could 

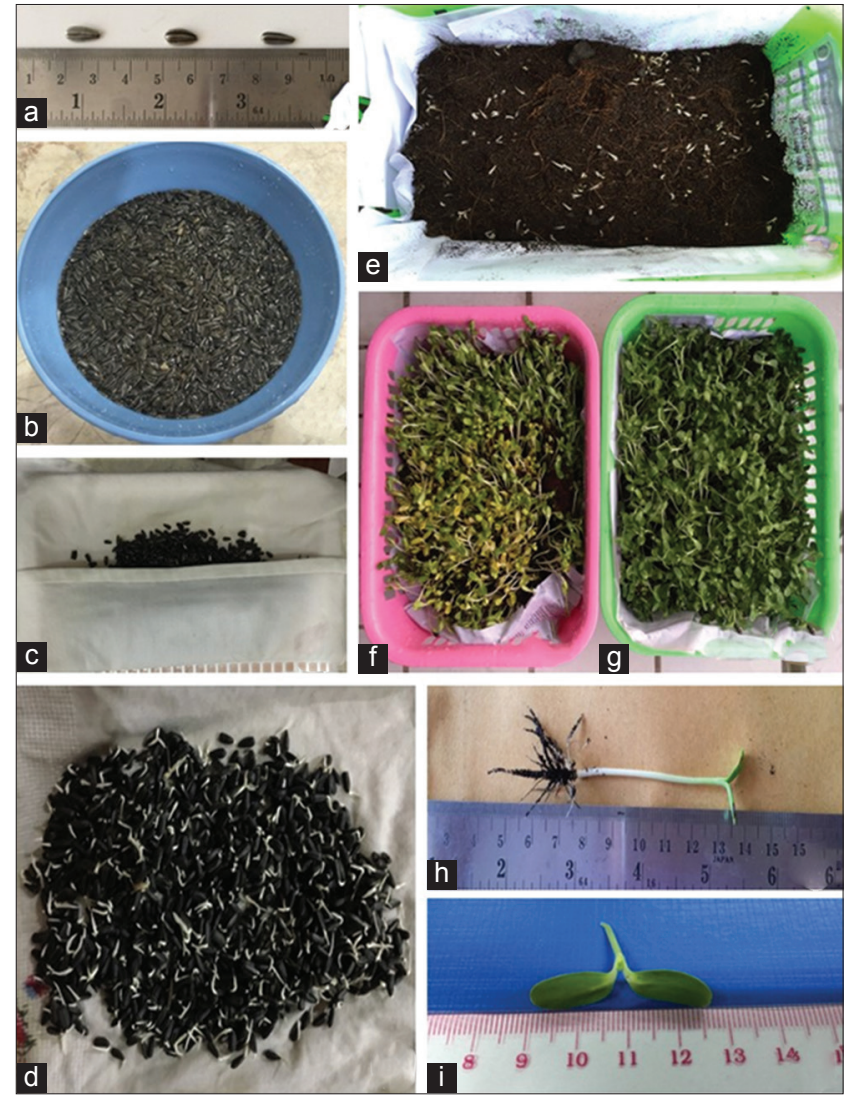

Fig. 1: How to grow the Helianthus annuus sprout (a) seed measurements; (b) soaking time; (c) damp towel; (d) germination; (e) sprouting tray; (f) before sun exposure; (g) after sun exposure; (h) grow-up sprout; (i) two-leaf stage

inhibit the elongation of roots and promote the accumulation of free amino acid. Under the light of ultraviolet B, hypocotyl length, and the activity of antioxidant enzymes were improved significantly. Overall, red light was more beneficial for the culture of sunflower sprouts.

\section{PHYTOCHEMICAL SUBSTANCES}

The sprout of $H$. annuus consists of the important constituents of pharmacological activities. Phenolic compounds: The phenolic compounds are caffeic acid, chlorogenic acid, caffeoylquinic acid, glucoside, glucopyranoside, cynarine, gallic acid, protocatechuic, coumaric, ferulic acid, and sinapic acids [13-15]. Flavonoids: Various flavonoids isolated from this plant are heliannone, quercetin, kaempferol, luteolin, apigenin [16]. Pigments: The pigments in sunflower are chlorophyll, carotene, and xanthophyll [17]. Fatty acids: The fatty acids composition in cotyledons are linoleic, palmitic, stearic acid, and oleic acids [18-20]. Vitamins: It contains a high concentration of vitamin A, B, C, and E and also niacin. Minerals: The minerals isolated from this plant are calcium, iron, magnesium, phosphorus, potassium, selenium, and zinc [21].

\section{TRADITIONAL USES}

In a review, Saini and Sharma [8] described the traditional uses of H. annuus like food and source of different disease treatment. It is used for antiaging [17], antidiabetic [22-24], antimicrobial activity [25,26], and antioxidant $[19,27]$. It also uses the other parts of this plant in the prevention of hepatic disease [28], nephrolithiasis [29], and heart disease [30]. Besides of the medicinal uses, the environmental protection by biodegradation [31] and phytoremediation was studied by this plant $[32,33]$ and also in biodiesel production plant $[34,35]$.

\section{ANTIOXIDANT ACTIVITY}

The process of germination of edible seeds to produce sprouts increases their nutritive value [4]. Several studies have reported higher levels of nutrients in sprouts compared to the un-germinated seeds [15,36-38]. Moreover, the sprouts are valuable dietary components as the sources of antioxidative phytochemicals $[19,39]$, however, information that of sunflower sprout is scarce. A comprehensive search of major databases included Sciencedirect, Springerlink, PubMed, and Google Scholar was conducted during the period 2005-2015 to retrieve available information about the antioxidant property of sunflower, $H$. annuus sprout. Different combinations of keywords as well as synonyms for keywords were used during the searches. Information on phytochemical activities was also retrieved and may be of interest; however, the primary focus of this review is not on those activities.

In 2009, Pasko et al. [39] reported higher total phenolic and flavonoid content in sprouts compared to seeds, suggesting that synthesis of antioxidants during germination may occur. It is thought that seeds mainly act as a reservoir for the development of the sprouts [40]. Next year, Casals and Zevallos [37] evaluated the 13 edible seeds for the level of phenolic compounds and the antioxidant activity at different germination states (dormant, imbibed, and $7 \mathrm{~d}$ sprouts). Selected seeds included alfalfa, broccoli, fava, fenugreek, kale, lentil, mung bean, mustard, onion, radish, soybean, sunflower, and wheat. The authors reported the phenolic and total antiradical capacity showed the general trend distribution of $7 \mathrm{~d}$ sprouts $>$ dormant seeds $>$ imbibed seeds. In addition, $7 \mathrm{~d}$ sunflower sprouts had the higher total antiradical capacity $\left(40,202 \mu \mathrm{g}\right.$ Trolox $\left.\mathrm{g}^{-1}\right)$ compared to other seeds $(1456-25,991 \mu \mathrm{g}$ Trolox g ${ }^{-1}$ ). Moreover, in 2012, Baczek-Kwinta and Sala [19] reported the antioxidant activities of sunflower sprout were 1.2 chlorogenic acid equivalent $\mathrm{g}^{-1}$ of free radical scavenging activity, 0.3 chlorogenic acid equivalent $\mathrm{g}^{-1}$ of ferric reducing antioxidant power, $2.49 \mathrm{mg} \mathrm{g}^{-1}$ of chlorophyll, $4.75 \mathrm{~g}^{-1}$ of flavonoid, and $130 \mu \mathrm{g} \mathrm{g}{ }^{-1}$ of anthocyanin. In recent year, 2014, Pajak et al. [15] reported total phenolic content in the seeds and sprouts of sunflower were 4 and $9 \mathrm{mg} \mathrm{g}^{-1}$ gallic acid equivalent. They also reported the flavonoids content in the seeds and sprouts of sunflower were 25 and $45 \mathrm{mg} \mathrm{g}^{-1}$ quercetin equivalent. H. annuus contains several kinds of the phenolic profile.

\section{CONCLUSION}

Why you need to add the sprouts in your daily meal because they are a lot of benefits. They contain fewer calories but are excellent sources of nutrients, easily grow so you can do by yourself without any soil or sunlight. Recent researches were found that sprouts have essential therapeutic benefits and have the ability to protect consumers from diseases. H. annuus is the source of various chemical constituents which are used for the treatment of many fatal or life-threatening diseases. Sunflower sprouts are a quintessential seed sprouting variety because of their large size, tasty, chlorophyll-rich leaves and succulent white stems. Sunflower sprouts are not only delicious but they are also quite nutritious and are rich in a number of vitamins and minerals as well as amino acid, fatty acid and fiber.

\section{ACKNOWLEDGMENTS}

This review article was funded in part by the Thailand Research Fund and the Commission on Higher Education: Research Grant for MidCareer University Faculty. Thanks should be addressed to the members of the Fish Research Unit, Department of Pathobiology, Faculty of Science, Mahidol University for their support. The author also many thanks to anonymous reviewers and editor for their perceptive comments on, and positive criticism of this review article.

\section{REFERENCES}

1. Laila O, Murtaza I. Seed sprouting: A way to health promoting treasure. Int J Curr Res Rev 2014;6(23):70-4 
2. Yang Y, Meier F, Lo JA, Yuan W, Sze VL, Chung HJ, et al. Overview of recent events in the microbiological safety of sprouts and new intervention technologies. Compr Rev Food Sci Food Saf 2013;12(3):265-80

3. Robertson LJ, Johannessen GS, Gjerde BK, Loncarevic S Microbiological analysis of seed sprouts in Norway. Int J Food Microbiol 2002;75(1-2):119-26.

4. Marton M, Mandoki ZS, Csapo-Kiss ZS, Csapo J. The role of sprouts in human nutrition. Acta Univ Sapientiae, Aliment 2010;3:81-117.

5. Martínez-Villaluenga $\mathrm{C}$, Frías $\mathrm{J}$, Gulewicz $\mathrm{P}$, Gulewicz $\mathrm{K}$, Vidal-Valverde C. Food safety evaluation of broccoli and radish sprouts. Food Chem Toxicol 2008;46(5):1635-44.

6. US FDA. Raw Produce: Selecting and Serving it Safely. Maryland, USA: U.S. Food and Drug Administration; 2012

7. Bashir T, Mashwani ZR, Zahara K, Haider S, Mudrikah TS. Chemistry, pharmacology and ethnomedicinal uses of Helianthus annuus (sunflower): A review. Pure Appl Biol 2015;4(2):226-35

8. Saini S, Sharma S. Helianthus annuus (Asteracea): A review. Int J Pharm Prof Res 2011;2:465-70.

9. Dwivedi A, Sharma GN. A review on Heliotropism plant: Helianthus annuus L. J Phytopharmacol 2014;3(2):149-55.

10. Owens GL, Rieseberg LH. Hybrid incompatibility is acquired faster in annual than in perennial species of sunflower and tarweed. Evolution 2014;68(3):893-900.

11. Lim TK. Edible Medicinal and Non-Medicinal Plants: Helianthus annuus. Dordrech: Springer Science and Business Media; 2014.

12. Xing ZN, Zhang D, Li W, Zhang H, Zhang L, Cui J. Effects of light quality on the growth and quality of Helianthus annuus sprouts. J Nanjing Agric Univ 2012;35(3):47-51

13. Weisz GM, Kammerer DR, Carle R. Identification and quantification of phenolic compounds from sunflower (Helianthus annuus L.) Kernels and shells by HPLC-DAD/ESI-MS. Food Chem 2009;115(2):758-65.

14. Amakura Y, Yoshimura M, Yamakami S, Yoshida T. Isolation of phenolic constituents and characterization of antioxidant markers from sunflower (Helianthus annuиs) seed extract. Phytochem Lett 2013;6(2):302-5.

15. Pajak P, Socha R, Galkowska D, Roznowski J, Fortuna T. Phenolic profile and antioxidant activity in selected seeds and sprouts. Food Chem 2014:143:300-6.

16. Kamal J. Quantification of alkaloids, phenols and flavonoids in sunflower (Helianthus annuus L.). Afr J Biotechnol 2011;10(16):3149-51.

17. Alda S, Moldovan C, Dogaru D, Alda L, Nita L. The dynamic of pigments level in sunflower sprouts after zinc compounds supplementing in growth. J Hortic Forest Biotechnol 2011;15(2):212-6.

18. Munshi SK, Sandhu S, Sharma S. Lipid composition in fast and slow germinating sunflower (Helianthus annuиs L.) Seeds. Gen Appl Plant Physiol 2007:33(3-4):235-46.

19. Baczek-Kwinta R, Sala A. What the antioxidant activity of sprouts depends on? Oxid Commun 2012;35(4):990-1000

20. Lee YH, Song HL, Piao XM, Park KH, Nam SY, Kim IJ, et al. Variations of seed traits, oil content and fatty acid composition in sunflower accession. Korean J Crop Sci 2010;55:245-52.

21. Blicharska E, Komsta L, Kocjan R, Gumieniczek A, Kloc A, Kazmierczak J. Determination of microelements in sprouts grown on metal-enriched solutions by ion chromatography. Acta Chromatographica 2014;26(4):739-47.

22. Sun Z, Chen J, Ma J, Jiang Y, Wang M, Ren G, et al. Cynarin-rich sunflower (Helianthus annuus) sprouts possess both antiglycative and antioxidant activities. J Agric Food Chem 2012;60(12):3260-5.

23. Luka CD, Tijjani H, Joel EB, Ezejiofor UL, Onwukike P. Hypoglycaemic properties of aqueous extracts of Anacardium occidentale, Moringa oleifera, Vernonia amygdalina and Helianthus annuиs: A comparative study on some biochemical parameters in diabetic rats. Int J Pharm Sci Invent 2013;2(7):16-22. Available from: http://www.ijpsi.org/Papers/ Vol2(7)/Version-1/D0271016022\%20.pdf.

24. Saini S, Sharma S. Antidiabetic effect of Helianthus annuus L., Seeds ethanolic extract in streptozotocin-nicotinamide induced Type 2 diabetes mellitus. Int J Pharm Pharm Sci 2013;5(2):382-7.

25. Subashini R, Rakshitha SU. Phytochemical screening, antimicrobial activity and in vitro antioxidant investigation of methanolic extract of seeds from Helianthus annuus L. Chem Sci Rev Lett 2012;1(1):30-4.

26. Ibrahim TA, Ajongbolo KF. Phytochemical screening and antimicrobial activity of crude extracts of Basella alba and Helianthus annuus on selected food pathogens. J Microbiol Biotechnol 2014;3(2):27-31.

27. Nadeem M, Anjum FM, Hussain S, Khan MR, Shabbir MA. Assessment of the antioxidant activity and total phenolic contents of sunflower hybrids. Pak J Food Sci 2011;21(1-4):7-12.

28. Vasavi A, Satapathy DK, Tripathy S, Srinivas K. Evaluation of hepatoprotective and antioxidant activity of Helianthus annuss flowers against carbon tetrachloride $\left(\mathrm{CCl}_{4}\right)$-induced toxicity. Int $\mathrm{J}$ Pharmacol Toxicol 2014;4(2):132-7

29. Khan NI, Shinge S, Naikwade NS. Antilithiatic effect of Helianthus аппииs Linn. Leaf extract in ethylene glycol and ammonium chloride induced nephrolithiasis. Int J Pharm Pharm Sci 2010;2(4):180-4.

30. Fei Y, Zhao J, Liu Y, Li X, Xu Q, Wang T, et al. New monoterpene glycosides from sunflower seeds and their protective effects against H2O2-induced myocardial cell injury. Food Chem 2015;187:385-90.

31. Podlipná R, Pospíšilová B, Vanek T. Biodegradation of 2 , 4-dinitrotoluene by different plant species. Ecotoxicol Environ Sa 2015;112:54-9.

32. Kara Y, Koca S, Vaizogullar HE, Kuru A. Studying phytoremeiation capacity of jojoba (Simmondsia chinensis) and sunflower (Helianthus annuus) in hydroponic systems. Curr Opin Biotechnol 2013;24:S34.

33. Laporte MA, Sterckeman T, Dauguet S, Denaix L, Nguyen C. Variability in cadmium and zinc shot concentration in 14 cultivars of sunflower (Helianthus annuиs L.) As related to metal uptake and partitioning. Environ Exp Bot 2015;109:45-53.

34. Barontini F, Simone M, Triana F, Mancini A, Ragaglini G, Nicolella C. Pilot-scale biofuel production from sunflower crops in central Italy. Renew Energy 2015;83(C):954-62.

35. Leiva-Candia DE, Tsakona S, Kopsahelis N, García IL, Papanikolaou S, Dorado MP, et al. Biorefining of by-product streams from sunflowerbased biodiesel production plants for integrated synthesis of microbial oil and value-added co-products. Bioresour Technol 2015;190:57-65.

36. Oloyo RA. Chemical and nutritional quality changes in germinating seeds of Cajanus cajan L. Food Chem 2004;85(4):497-502.

37. Casals BA, Zevallos LC. Impact of germination on phenolic conten and antioxidant activity of 13 edible seed species. Food Chem 2010;119(4):1485-90

38. Villaluenga CM, Penas E, Ciska E, Piskula MK, Kozlowska $H$, Valverde $\mathrm{CV}$, et al. Time dependence of bioactive compounds and antioxidant capacity during germination of different cultivars of broccoli and radish seeds. Food Chem 2010;120(3):710-6.

39. Pasko P, Barton H, Zagrodzki P, Gorinstein S, Fołta M, Zachwieja Z. Anhocyanins, total polyphenols and antioxidant activity in amaranth and quinoa seeds and sprouts during their growth. Food Chem 2009;115(3):994-8

40. Perez-Balibrea S, Moreno DA, Garcia-Viguera C. Genotypic effects on the phytochemical quality of seeds and sprouts from commercia broccoli cultivars. Food Chem 2011;125(2):348-54. 